\title{
NURSING CARE SYSTEMATIZATION AS A MULTIDIMENSIONAL AND INTERACTIVE PHENOMENON
}

\author{
Dirce Stein Backes ${ }^{1}$ \\ Magda Santos Koerich ${ }^{2}$ \\ Keyla Cristiane do Nascimento ${ }^{3}$ \\ Alacoque Lorenzini Erdmann ${ }^{4}$
}

Backes DS, Koerich MS, Nascimento KC, Erdmann AL. Nursing care systematization as a multidimensional and interactive phenomenon. Rev Latino-am Enfermagem 2008 novembro-dezembro; 16(6):979-985.

This study aimed to understand the meaning of Nursing Care Systematization (NCS) for multiprofessional health team professionals based on the relationships, interactions and associations of Complex thought. This qualitative study uses Grounded Theory as a methodological reference framework. Data were obtained through interviews with three sample groups, totaling 15 professionals from different institutions. Simultaneous data codification and analysis identified the central theme: "Glimpsing nursing care systematization as an interactive and multidimensional phenomenon" and the respective reference model. NCS appoints, in addition to interactivity and professional complementarity, the importance of dialog and connection between the academy, health practices and regulatory offices, based on new reference frameworks for the organization of health practices.

DESCRIPTORS: nursing; nursing process; patient care team

\section{SISTEMATIZACIÓN DE LA ASISTENCIA DE ENFERMERÍA COMO FENÓMENO INTERACTIVO Y MULTIDIMENSIONAL}

La presente investigación buscó comprender el significado de la Sistematización de la Asistencia de Enfermería (SAE) para los profesionales del equipo multiprofesional bajo la perspectiva de las relaciones, interacciones $y$ asociaciones del pensamiento complejo. Se trata de un estudio cualitativo, que tiene como marco metodológico la Teoría Fundamentada en los Datos (Grounded Theory). Los datos fueron obtenidos por medio de entrevistas con tres grupos de muestra, sumando quince profesionales del equipo multiprofesional de la salud pertenecientes a diferentes instituciones. La codificación y el análisis simultáneo de los datos posibilitaron la identificación del tema central: Vislumbrando sistematizar la asistencia de enfermería como fenómeno de interacción y multidimensional y el respectivo modelo de referencia. La SAE apunta más allá de la interactividad y complementariedad profesional, la importancia del diálogo y la circulación entre la academia, las prácticas de salud y los órganos legisladores a partir de nuevas referencias para la organización de las prácticas en salud.

DESCRIPTORES: enfermería; procesos de enfermería; grupos de atención al paciente

\section{SISTEMATIZAÇÃO DA ASSISTÊNCIA DE ENFERMAGEM COMO FENÔMENO INTERATIVO E MULTIDIMENSIONAL}

A presente investigação buscou compreender o significado da Sistematização da Assistência de Enfermagem (SAE) para os profissionais da equipe multiprofissional à luz das relações, interações e associações do pensamento complexo. Trata-se de estudo qualitativo, tendo como referencial metodológico a Teoria Fundamentada nos Dados (Grounded Theory). Os dados foram obtidos por meio de entrevistas com três grupos amostrais, somando quinze profissionais da equipe multiprofissional da saúde pertencentes a diferentes instituições. A codificação e a análise simultânea dos dados possibilitaram a identificação do tema central: Vislumbrando a sistematização da assistência de enfermagem como fenômeno interacional e multidimensional e o respectivo modelo de referência. A SAE aponta, para além da interatividade e complementaridade profissional, a importância da dialogicidade e circularidade entre a academia, as práticas de saúde e os órgãos legisladores a partir de novos referenciais para a organização das práticas em saúde.

DESCRITORES: enfermagem; processos de enfermagem; equipe de assistência ao paciente

Universidade Federal de Santa Catarina, Brazil:

${ }^{1}$ RN, Doctoral student, e-mail: backesdirce@ig.com.br;; ${ }^{2}$ RN, Doctoral student, Assistant Professor, e-mail: magmau@matrix.com.br; ${ }^{3}$ RN, Doctoral student, e-mail: mda_keyla@yahoo.com; ${ }^{4}$ RN, Ph.D in Nursing Philosophy, Full Professor, e-mail: alacoque@newsite.com.br. 


\section{INTRODUCTION}

$\boldsymbol{I}_{\mathrm{n}}$ view of the increasing advancement of science and technology, a frequent question is asked: How and in what sense has the scientific revolution contributed to the improvement of practices in the health area? While it has brought considerable benefits to a wide range of work areas, on the other hand, it has contributed to fragment knowledge and consequently, led to fragmented care delivery.

Under this perspective, advancements and discoveries need to be questioned and confronted with new epistemological possibilities, capable of questioning and re-orienting nursing reasoning in a multidimensional perspective ${ }^{(1)}$.

Thus, it should be acknowledged that great advancements in the nursing area resulted in the implementation of the nursing process. This expression was first proposed in 1961 as activity related to the organization and planning of care delivered to the human being in its integral form ${ }^{(2)}$. The nursing process is based on the Theory of Basic Human Needs and comprises a set of systematized and inter-related stages, oriented towards the organization and planning of the care delivered to human beings. In this approach, however, the view of nursing care as an end in itself prevailed and little consideration was given to patients' experiences and expectations, as well as to interactions with other health professionals ${ }^{(3)}$.

The nursing process emerged in this context to assure and guarantee professional autonomy through the systematization of nursing actions ${ }^{(4)}$. Based on these initial conceptions, the process gained new meanings and expressions and began to be called - Nursing Care Systematization (NCS), most of the times adapted to the North-American Nursing Classification $^{(5-6)}$

With the approval of the Professional Nursing Practice Law, which establishes the nursing prescription $^{(7)}$ as nurses' private attribution, the care process became the main concern of Brazilian professionals. In this context, NCS has been the theme of several studies, whether in education or health services, aiming to qualify scientific nursing care knowledge, assure individualized care and professional autonomy ${ }^{(8-11)}$.

Authors on the Complex thought, however, criticize safe and ordered methodological models that lead to inflexible knowledge ${ }^{(12-14)}$. They argue that inflexible and linear traditional methods fragment the complex reality, tear down and treat the human being and social phenomena in a one-dimensional way.

In this perspective, it is imperative to search for more dynamic, cooperative and interdisciplinary reference frameworks, that is, processes that value the multidimensionality of the human being, and also integrate knowledge from different areas. That is, care based on the precepts of complexity, able to provide more effective interactions between health team professionals and permit users' participation.

The Complex thought allows for the development of more critical and creative perspectives on reality, that is, practices in which care interactions and associations are established on. On the other hand, the Complex thought encourages the dismantlement of objective cultural patterns and construction of epistemological strategies and reflexive and critical interdisciplinary practices ${ }^{(15)}$.

As members of the Study and Research Group on Nursing and Health Administration (GEPADES), who have attempted to deepen the complex thought in their research, we present the following question: What is the meaning of the NCS for the multi-professional health team?

Expecting to explore new perspectives through complex and interdisciplinary elements, this study aimed to understand the meaning of the NCS for multi-professional health team professionals, based on the Complex thought.

\section{METHOD}

Grounded theory was chosen among several qualitative methodologies, aiming to understand the meaning of phenomena based on data and action.

This methodology was originally developed by Glaser e Strauss, American sociologists, who attempted to construct a theory based on data acquired in the exploration of a phenomenon in the reality it is inserted in, while the theoretical construction explains action in the social context ${ }^{(16-17)}$.

Grounded theory is a qualitative and inductive research method that aims to generate new knowledge, based on systematically and concomitantly analyzed and compared research data. Knowledge is constructed based on social interaction and understanding of human activity and action in different 
scenarios. The procedures used aim to simultaneously identify, develop and relate data, so that theoretical and methodological relevance is achieved ${ }^{(18)}$.

Data collection was carried out through interviews of 40 minutes on the average, at two health institutions in Florianópolis, SC, Brazil. Interviewees answered to the following questions: What does Nursing Care Systematization mean to you? How has it been applied in health practice?

Interviews were carried out with three sample groups according to the research method. The first group was composed of ten professionals, members of multi-professional health teams, who work in medical and surgical units. The participants, selected by the nursing head, were asked about their availability and willingness to participate in the study.

The second group was composed of the Heads of the Nursing Service at the studied health institutions, with a view to the hypotheses that emerged from the first group. These hypotheses indicate a divergent and not very clear view on the theme of this study. The guiding question was the same, though more in depth, so as to understand the philosophy, references, and how NCS has been addressed in the relational, interactive and associative processes in these institutions' practice.

One of the participants from the second sample group frequently mentioned the State Nursing Council (COREN), i.e. the regional nursing supervising agency. This participant stated that, apparently, the agency does not have a clear and proper understanding of what NCS really is. Therefore, we considered it important to understand what NCS means for professionals working at COREN. Thus, two professionals who directly work with the surveillance of nursing services were asked: What does NCS mean to you? How has NCS been applied and supervised in health institutions?

For theoretical sampling, we attempted to collect data that supported the theoretical construction so that, when simultaneously collecting, codifying and analyzing them, theoretical saturation would be achieved. This was accomplished after 15 interviews, carried out between November 2006 and May 2007.

Data were transcribed and reviewed in detail for each interview. Then, identification of conceptual units began. Data were codified line-by-line, compared and selected in categories. In the following stage, the researchers chose an open coding category - first stage of codification - and put it as the central theme, comparing it with the remaining categories. In the following phase, also called axial coding, data were grouped in new forms, seeking to expand and compact the emergent theory based on theoretical connections. In this phase, we attempted to perform the theoretical unveiling of NCS based on the causal context, intercedents, consequences and strategies, trying to absorb as most as possible the relations and interactions underlying data. After analysis and subsequent reduction of categories, theoretical knowledge was established and the central theme was achieved ${ }^{(17)}$.

The study complied with recommendations of Resolution 196/96 by the National Health Council, which incorporates, under the individuals' and groups' view, the four basic references of bioethics: autonomy, non-maleficence, beneficence and justice, among others. It also assures rights and duties regarding the scientific community, research subjects and the State ${ }^{(19)}$. Thus, the participants' agreement was obtained through the signing of the Free and Informed Consent Term. The project was approved by the Research Ethics Committee at the Federal University of Santa Catarina under No. 0291/06.

To assure anonymity to those involved in the study, reports were identified in the text with a letter and followed by a number (P1, P2...).

\section{RESULT ANALYSIS AND DISCUSSION}

Glimpsing nursing care systematization as an interactive and multidimensional phenomenon emerged as the central theme in the categories codification, comparison and summarizing process. That is, it comprises the essence and/or heart of the categories' codification and integration process.

The central expression Glimpsing nursing care systematization as an interactive and multidimensional phenomenon indicates the need to re-think nursing theories and practices based on new reference frameworks. These frameworks need to cover the interactive and multi-dimensional nature of health care in a broad and complementary way. The key to construct reference frameworks capable of linking parts and whole, amidst the knowledge revolution, needs to be based on interactive processes and interdisciplinary practices that can understand 
systematization in an integral and interconnected way, as some experiences have indicated: systematization is very broad. It is every process that involves client care, regardless of the area...systematization needs to be addressed as a whole, whether in nursing, nutrition or hotel, because we perceive that everything is interconnected, everything has to be systematized. Like in the laundry, if there is no clothing systematization process, the clothing delivery will be delayed, so nursing will have baths delayed... there will be no clothing at the surgical center (P11).

The existential logic of postmodern science needs to promote communicative attitudes based on interactions and intertextuality, organized around local projects of undivided knowledge, which aims for the totality and multidimensionality of phenomena. In this perspective, the nursing process also needs to be connected with different areas, all-inclusive and learned from human action conditions in different scenarios and work fields ${ }^{(20)}$.

The subcategories and categories were successively integrated into the central theme by theoretical unveiling in the social context, which departs from contextual conditions, strategies, causes, consequences and interposed elements, as determined by the reference model.

Thus, based on the theoretical unveiling, verifying the need for interactive, complementary and multi-professional care and perceiving lack of connection between knowledge, action and establishment of rules constituted the contextual categories that originated the central theme: Glimpsing nursing care systematization as an interactive and multidimensional phenomenon.

The category verifying the need for interactive, complementary and multi-professional care refers, to a greater or lesser extent, to NCS as relational tendency that needs to go beyond nursing, i.e. that needs to overcome limits of knowledge areas, move forward in a dialogical and complementary perspective towards other health professionals ${ }^{(21)}$. Under this view, the following subcategories become relevant: Identifying the need for professional complementariness in patient care; acknowledging NCS as the base for the work of other professionals; perceiving the need for continuing processes and understanding that other services indirectly provide care, which can be illustrated by the following comment: I'd like to stress that we perceive the need for multidisciplinary elements to better attend the patient... I also understand that we need very clear communication between professionals, so that patients feel safe and respected... (P3).
These observations get more evident in those professionals who directly attend patients, especially nurses who, often used to individual action, do not perceive the importance of interconnected health practices and, mainly, of the care system. Professionals raise these questions when they state: the problem I see in nursing is that it gazes at its own navel, as if other areas were not important. And all areas have to be interconnected. Because it's no use...Nursing does not work if hygiene does not do a good job. The question is that, when a patient leaves the hospital, he does not bad-mouth nursing, he bad-mouths the hospital. He bad-mouths the institution. So everybody has to be interconnected in the care process for this client, so that the effect is positive (P12).

Reports describe NCS expressed in nurses' action, as a cartesian model, also called reductionist, which divides the whole in parts and studies them separately. NCS can be fitted in the simplification paradigm, whose knowledge is dualist, subjective or objective, collective or individual ${ }^{(12)}$.

Under this perspective, how can dialogical attitudes be promoted, based on interaction among knowledge areas with a view to NCS? How can NCS answer the multiple questions asked in the different areas of professional knowledge? These and other questions gradually need to be included in nursing thinking and action in postmodern times.

The category perceiving lack of connection between knowledge, action and establishment of rules refers to the gap between academy, health practice and professional regulation offices, as well as to the lack of opportunity to dialog and propose questions related to NCS. At the same time as the category shows fragmentation of nursing actions, it also indicates a new paradigm, capable of valuing common sense and practical knowledge, which guide actions and bestow meanings upon different interactional phenomena $^{(13)}$.

Professionals, especially those involved in administrative and/or management functions in the care system, perceive an increasing gap between knowledge produced in the academy and practice. They believe this can be contributing to decrease the value of NCS and even hindering the development of more flexible and dialogical processes in an interdisciplinary perspective. I don't know to what extent we've been valuing NCS in the curricula... I think that some nurses, when they graduate, don't believe in the systematization of care. There is a gap between the knowledge produced in the academy 
and what the services absorb of this knowledge production... it is not enough to simply have care systematization as a method, it's got to be based on a philosophy (P13).

The gap between academy and health practices, as well as the diminished valorization of NCS by some professionals, can also be related to different conceptions and meanings of the same phenomenon, as showed by the reports: I don't take into account recommended COREN processes, which COREN is working with and is demanding from institutions, but the systematization of care (P12). The university is teaching NCS out of reality, with no application because it doesn't know the nurses' practice and health services... the practice depends on the management, which is still based on bureaucratic issues, it is not concerned with the care results, but with costs... the regulating offices need to know the nurses' practice... help in the construction of NCS so that it can comply with the reality of health services and not only establish rules to be complied with(P15).

The reports invite to a careful consideration and critical review with a view to decreasing the gap between being and doing, through connections or interdependencies, in an effort to promote dialog between the simple and the complex ${ }^{(12)}$.

The categories acknowledging NCS as an instrument to guide care and associating NCS to the organization chart, set of rules and surveillance emerged from the subcategories: acknowledging the importance of NCS as a guiding instrument; acknowledging the importance of NCS for patients and team; stressing the importance of information in the patient file and acknowledging NCS as a form of organization and orientation of nursing care. These constitute strategies to improve quality, interactivity and multidimensionality of care in the health context. Besides orienting the organization to the care system, NCS also provides greater autonomy to nursing professionals. It means a method of organizing the work process in terms of recording information and it also directs care to be delivered to the patient, providing nurses with an evaluation instrument and directing care to be performed by the nursing team(P15).

Despite efforts, NCS as it has been applied so far is still based on the premise of nurses determining the health care system, based on their view of the world, society and human beings. Choices of what to do and how to do it, however, need to be discussed and negotiated with the health team and with patients, accepting them as beings with conscience, autonomy and capacity to think ${ }^{(3)}$.
The categories verifying the fragmentation of health care and perceiving NCS as an automated process are determinants for the development of thought and action in the perspective of complexity, that is, complex care. The professionals' reports indicate that NCS is often an automated process, mechanically performed in daily routine, aggravated by the insufficient number of nursing professionals, task division, divergent information, discontinued care and excessive bureaucratization of the current health system itself. I think that people act mechanically... I guess some have seen NCS in an automated way, so I even get concerned with IT: I press a little button and the prescription is done. Because we see prescriptions are repeated (P2). So these questions appoint to systematization, especially the evolution and nursing prescription, they became mechanized (P12).

The category perceiving the need for a single instrument for all professionals emerged as a consequence of excessive bureaucratization and fragmentation of practices related to the care performed by various professionals. In this perspective, the following categories become relevant: perceiving the need for a channel and/or single instrument of information; adapting systematization to other areas through operational procedures; stressing the importance of identifying all professionals in patients' files.

Perceiving the need for a single instrument for all professionals shows the complexity of health practices. No professional is, by (her)himself, able to answer the different dimensions that involve care to the patient in the totality of the self. Systematization was very connected to nursing, as it owned the truth. So, what we did. The SOPS - operating procedures, which end up being universal at the hospital for all areas directly or indirectly related in this process...(P11). All areas of knowledge need to be connected with a view to a complex, flexible care and the care humanization paradigm ${ }^{(3)}$

The category acknowledging in the nurse professional a bridge of communication between professionals is presented as intercedent for the achievement of more interactive and complementary heatlh care practices. Health professionals acknowledge the nurse as an element able to connect and integrate different areas of knowledge, especially because nurses work closely with patients and easily detect alterations that can occur during the 24 hours of a day. However, the nurse has to concentrate interactions and value different forms of thinking with 
a view to understanding correlations between parts/ whole and the human being as a complex being. In summary, the subcategories reflect that nurses are acknowledged and valued because they are in different health scenarios, even if they need to be accompanied by more interactive and complementary processes, as reports show: I think it is our achievement, I mean, consolidating the space of nursing, of nurses' work (P4); because nursing is always close to the patients, detects their needs and informs us (P7).

Seeing NCS as a broad and complex phenomenon implies, in addition to the interactivity and complementariness of health professionals, the connection between academy, health practices and regulating offices, based on more flexible, creative and dynamic references.

\section{FINAL CONSIDERATIONS}

The central theme Glimpsing nursing care systematization as an interactive and multidimensional phenomenon opens up new and complex possibilities for the nursing services and care system. It presents the reference model found and is composed of the categories: verifying the need for interactive, complementary and multi-professional care and perceiving lack of connection between knowledge, action and establishment of rules as contextual conditions; acknowledging NCS as an instrument to guide care and associating NCS to the organization

\section{REFERENCES}

1. Figueiredo RM, Zem-Mascarenhas SH, Napoleão AA. Caracterização da produção do conhecimento sobre sistematização da assistência de enfermagem no Brasil. Rev Esc Enferm USP 2006 abril; 40(2): 299-303.

2. Silva EM, Gomes ELR, Anselmi ML. Enfermagem: realidade e perspectiva na assistência e no gerenciamento. Rev Latinoam Enfermagem 1993 janeiro; 3(1): 53-64.

3. Silva AL, Ciampone MHT. Um olhar paradigmático sobre a asistencia de enfermagem - um caminhar para o cuidado complexo. Rev Esc Enferm USP 2003 outubro; 37(4):13-23.

4. Horta WA. Processos de Enfermagem. São Paulo (SP): EPU/Ed. Universidade de São Paulo; 1979.

5. Santos SR, Paula AFA, Lima JP. O enfermeiro e sua percepção sobre o sistema manual de registro no prontuário. Rev Latino-am Enfermagem 2003 janeiro; 11(1): 80-7.

6. North American Nursing Diagnosis Association (NANDA). Diagnósticos de Enfermagem da NANDA: Definições e Classificação. 2005-2006. Porto Alegre (RS): Artmed; 2006. chart, set of rules and surveillance as strategies, verifying the fragmentation of health care and perceiving NCS as an automated process as potential determinants. Likewise, perceiving the need for a single instrument for all professionals emerged as a consequence of excessive bureaucratization and fragmentation of practices related to the care performed by several professionals and acknowledging in the nurse professional a bridge of communication between professionals as intercedent for the achievement of interactive and complementary care practices in health.

Results indicate that NCS can be put in practice to the extent that dialogical and reflexive strategies are developed in the health community, capable of exposing reducionist actions related to merely technical and bureaucratic work. In summary, NCS is showed as an important instrument of information because it favors the implementation of care standards and criteria and establishes care priorities.

NCS also reveals to be an important element to connect and coordinate improvement processes in the interdisciplinary health context, provided that it is expanded and considered beyond nursing organization. Thus, much more than criticizing, results aim to expose issues of care practice through a dynamic movement of construction and reconstruction of knowledge, besides leading to a proposed change in paradigms for achieving a "new space" in nursing and health.

7. Conselho Federal de Enfermagem. Resolução n. 272, de 27 agosto 2002. Dispõe sobre a Sistematização da Assistência de Enfermagem - SAE - nas Instituições de Saúde Brasileiras. Rio de Janeiro: COFEN; 2002.

8. Backes DS, Esperança MP. Sistematização da assistência de enfermagem: percepção dos enfermeiros de um hospital filantrópico. Acta Sci Health Sci. Maringá. 2005; 27(1): 25-9.

9. Feijão AR, Carvalho MFC, Teixeira F. Avaliação da sistematização da assistência de enfermagem em hospital de doenças infecciosas. Online Braz J Nurs 2006; 5(2): $1-10$.

10. França FCV, Kawaguchi IAL, Silva EP, Abrão GA, Uemura $H$, Alfonso LM, et al. Implementação do diagnóstico de enfermagem na unidade de terapia intensiva e os dificultadores para enfermagem - relato de experiência . Rev Eletrônica Enferm 2007; 9(2): 537-46.

11. Vasconcelos FF, Araújo TLde, Moreira TMM, Lopes MVO. Association among nursing diagnoses, demographic variables, and clinical characteristics of patients with high blood pressure. Acta Paul Enferm 2007; 20(3): 326-32. 
12. Morin E. Para sair do século XX. Rio de Janeiro (RJ): Nova Fronteira; 1986.

13. Morin E. A cabeça bem feita: repensar a reforma, reformar o pensamento. Rio de Janeiro (RJ): Bertrand Brasil; 2001. 14. Morin E. Ciência com consciência. Rio de Janeiro (RJ): Bertrand Brasil; 2003.

15. Vasconcelos EM. Complexidade e pesquisa interdisciplinar: epistemologia e metodologia operativa. Petrópolis (RJ): Vozes; 2004.

16. Strauss A, Corbin J. Basics of qualitative research: grounded theory procedures and techniques. Thowand Lage Daks: Lage Publications; 1990.

17. Strauss A, Corbin J. Bases de la investigación qualitative: tecnicas y procedimientos para desarrollar la teoría fundamentada. Medellín: Ed. Universidad de Antioquia; 2002. 18. Santos LHP dos, Cassiani SHB. Vivendo em constante conflito: o significado da prática docente no ensino médio de enfermagem. Rev Latino-am Enfermagem 2000 outubro; 8(5): 58-64.

19. Ministério da Saúde (BR). Resolução $n^{\circ}$. 196. Diretrizes e normas técnicas regulamentadoras de pesquisa envolvendo seres humanos. Brasília (DF): MS; 1996.

20. Santos BS. Um discurso sobre as ciências. São Paulo (SP): Cortez; 2005.

21. Erdmann AL. Sistema de Cuidados de Enfermagem. Pelotas (RS): Universitária/UFPel; 1996. 